\title{
Faktor Yang Mempengaruhi Permintaan Konsumen Terhadap Produk Minyak Kelapa ( Minyak Mandar) Desa Patampanua Kecamatan Matakali Kabupaten Polewali Mandar
}

\author{
Haeruddin $^{1}$, Zulkifli Basri ${ }^{2}$, Hamma Ahmad ${ }^{3}$ \\ Program Studi Agribisnis, Fakultas Ilmu Pertanian, Universitas Al Asyariah Mandar \\ Email : jepamandar@yahoo.com
}

\begin{abstract}
Abstrak
Produk merupakan segala sesuatu yang dapat ditawarkan produsen untuk diperhatikan, diminta, dicari, dibeli, digunakan, atau dikonsumsi pasar sebagai pemenuhan kebutuhan atau keinginan pasar yang bersangkutan. Kulitas produk dapat dilihat dengan adanya Kinerja, Fitur, Keandalan, Kesesuaian, Daya Tahan. Harga adalah jumlah uang yang harus dibayar pelanggan untuk memperoleh produk

Penelitiaan ini dilakukan Di Desa Patampanua Kecamatan Matakali Kabupaten Polewali Mandar selama 3 (tiga) bulan yakni bulan Desembersampai denganFebruari 2019. Adapun tujuan penelitian yaitu Untuk mengetahui Faktor apa saja yang mempengaruhi permintaan konsumen terhadap produk minyak Kelapa (minyak Mandar) dan untuk mengetahui bagaimana tanggapan konsumen terhadap faktor yang mempengaruhi Permintaan produk minyak kelapa (minyak mandar) Pemilihan kasus dengan cara purposive sampling. jumlah sempel penelitan sebesar 43 orang pengunah minyak goreng (minyak mandar) didesa Patampanuan Kecamatan Matakali Kabupaten Polewali Mandar.
\end{abstract}

Keywords : Prilaku Komsumen, Permintaan, Minyak Mandar

\section{Pendahuluan}

Pengenalan konsumen terhadap kebutuhan atas produk merupakan proses awal pengambilan keputusan. Kebutuhan untuk minyak merupakan suatu hal yang sangat penting dalam kehidupan manusia. Karena tanpa adanya minyak goreng, manusia tidak dapat mengoreng. Selain itu, minyak juga banyak mengandung vitamin yang diperlukan oleh tubuh. konsumen perlu mengetahui tentang karakteristik suatu produk, apabila konsumen kurang mengetahui informasi tentang karakteristik suatu produk bisa salah dalam mengambil keputusan membeli. Pelaku usaha yang berpengalaman akan memberikan informasi, pendidikan dan kepemahaman kepada setiap calon pembeli khususnya dan kepada masyarakat umumnya.

Produk merupakan segala sesuatu yang dapat ditawarkan produsen untuk diperhatikan, diminta, dicari, dibeli, digunakan, atau dikonsumsi pasar sebagai pemenuhan kebutuhan atau keinginan pasar yang bersangkutan. Kulitas produk dapat dilihat dengan adanya Kinerja, Fitur, Keandalan, Kesesuaian, Daya Tahan. Harga adalah jumlah uang yang harus dibayar pelanggan untuk memperoleh produk. Tempat meliputi kegiatan perusahaan yang membuat produk tersedia bagi pelanggan sasaran. Harga jual produk dibuat serendah mungkin, bahkan ada yang hingga rugi untuk menarik minat konsumen untuk membeli dan mencoba produk tersebut. Namun setelah produk ini memperoleh pangsa pasarnya, harga produk ini akan naik. Bagaimanapun juga, dalam jangka panjang perusahaan memerlukan keuntungan. Pemilihan lokasi mempunyai fungsi yang strategis karena dapat ikut menentukan tercapainya tujuan badan usaha. Pemilihan lokasi harus memperhatikan potensi pasar yang tersedia di sekitar lokasi tersebut.

Lokasi merupakan struktur fisik dari sebuah usaha yang merupakan komponen utama yang terlihat dalam membentuk kesan sebuah usaha yang dilakukan perusahaan dalam melakukan penempatan usahanya dan kegiatan dalam menyediakan saluran pelayanan yang dibutuhkan oleh konsumen (Utami,2012). Promosi merupakan faktor penentu keberhasilan suatu program pemasaran. Betapapun berkualitasnya sutu produk, bila konsumen belu pernah mendengarnya dan tidak yakin bahwa produk itu akan berguna bagi mereka, maka mereka tidak akan pernah membelinya Pada hakikatnya promosi adalah suatu bentuk komunikasi pemasaran Promosi berarti aktivitas yang menyampaikan manfaat produk dan membujuk pelanggan membelinya.

Industri minyak kelapa mandar merupakan salah satu industri pengolahan dengan mengolah bahan baku kelapa menjadi minyak kelapa. Minyak kelapa mandar merupakan sebuah kekayaan daerah yang berasal dari produksi kearifan lokal masyarakat yang diakui memiliki keunggulan tersendiri dan menjadi kebanggan masyarakat etnis Mandar. Potensi minyak kelapa di daerah Polewali Mandar dibuat dengan cara tradisional dan dijual dengan cara tradisional. Syarat untuk menembus pasar yang kompetitif harus memiliki potensi pengembangan produk minyak kelapa yang mampu berdaya saing. Potensi paling utama dari dari produk minyak mandar adalah cita rasa dan bauhnya.

Konsumen akan lebih selektif dalam menyeleksi produk minyak yang ditawarkan oleh para produsen agar produk yang dibelinya sesuai dengan kebutuhan. Adapun yang menjadi karakteristik konsumen ditentukan oleh 
beberapa faktor yaitu: faktor kebudayaan, faktor sosial, faktor pribadi, dan faktor psikologi. Keinginan masyarakat dalam memilih minyak karena masyarakat tumbuh dalam suatu lingkungan yang telah mengembangkan teknologi dengan seperangkat pemahaman dan nilai konsumen. Dengan adanya budaya menjalin silahturahmi dalam masyarakat Indonesia membuat produsen semakin ramai. Hampir setiap orang secara tetap melakukan interaksi dengan orang lain yang secara langsung atau tidak langsung juga akan mempengaruhi keputusan membeli mereka. Budaya masyarakat yang suka mencoba hal baru dan mengikuti tren dimanfaatkan produsen minyak yang dengan gencar meluncurkan produk-produk baru. Lingkungan masyarakat akan mempengaruhi keputusan. Teman, keluarga atau figur publik yang dapat mempengaruhi seseorang dalam pembelian, Konsumen mempunyai kepribadian yang berbeda-beda sehingga keputusan yang dibuat dalam memilih pun berbeda misalnya konsumen ada yang menyukai minyak dalam kemasan karena sesuai dengan gaya hidupnya. Pemilihan produk juga di pengaruhi kondisi ekonomi seseorang. Konsumen akan mempertimbangkan untuk membeli minyak yang mahal jika ia memiliki pendapatan yang cukup. Individu yang mempunyai kebutuhan, hasrat dan keinginan, akan membentuk suatu perilaku yang diharapkannya akan memenuhi kebutuhan. Dengan demikian akan menimbulkan keadaan yang lebih menyenangkan dalam dirinya.

Desa Patampanua Kecamatan matakali, memproduksi minyak goreng lokal yang dikenal dengan minyak kelapa Mandar, minyak goreng disukai masyarakat lokal untuk dikomsumsi. Minyak mandar yang terkenal dengan kelezatannya masih dikonsumsi masyarakat lokal secara tradisional di Kabupaten Polewali Mandar di Sulawesi Barat untuk kebutuhan konsumsi sehari-hari. Minyak goreng mandar diolah dengan menggunakan industri rumah tangga, yang peralatannya sederhana kemudian diperjual belikan masyarakat yang membuatnya secara tradisional pula, untuk selanjutnya dikonsumsi masyarakat dalam memenuhi kebutuhan makannya sehari-hari (Dikutif dari perkataan masyarakat). Sehubungan dengan hal tersebut di atas, maka penulis mencoba melakukan penelitian dengan judul "Faktor Yang Mempengaruhi Permintaan Konsumen Terhadap Produk Minyak Kelapa (Minyak Mandar) di Desa Patampanua Kecamatan Matakali, Kabupaten Polewali Mandar"

\section{Metode Penelitian}

\section{Pengumpulan Data}

Penelitian ini akan dilaksanakan di Desa Patampanua, Kecamatan Matakali, Kabupaten Polewali Mandar yang berlangsung selama 3 (tiga) bulan yakni Desember - Februari 2019 Data yang digunakan terdiri atas data primer dan data sekunder. Data primer yaitu data yang dikumpulkan melalui observasi langsung dan wawancara langsung dengan responden dengan menggunakan kuesioner/ daftar pertanyaan yang meliputi: IdentitasIdentitas responden (umur, tingkat pendidikan, tanggapan masyarakat tentang budaya, pendapatan, harga, kualiatas barang, ketersedian dan lokasi, dan promosi ). Data sekunder adalah data yang dikumpulkan melalui berbagai sumber yang terkait dengan usaha minyak mandar dengan data penelitian yang dibutuhkan. Misalnya: letak geografis, kondisi sosial (mata pencaharian, tingkat pendidikan, sarana dan prasarana).

\section{Analisis Data}

Penelitian Kualitatif adalah penelitian yang data hasil penelitian lebih berkenaan dengan interpretasi terhadap data yang ditemukan di lapangan (Sugiyono, 2011).Penelitian kualitatif yaitu penelitian dengan menggunakan metode ilmiah untuk mengungkapkan suatu fenomena dengan cara mendeskripsikan data dan fakta melalui kata-kata secara menyeluruh terhadap subjek penelitian (Mulyana, 2008).

Dalam penelitian ini peneliti menggunakan Penelitian Etnografi adalah suatu bentuk penelitian yang berfokus pada makna sosiologi melalui observasi lapangan dari fenomena sosiokultural. Biasanya para peneliti etnografi memfokuskan penelitiannya pada suatu masyarakat (tidak selalu secara geografis, juga memerhatikan pekerjaan, pengangguran, dan masyarakat lainnya). Penelitian etnografi khusus menggunakan tiga macam pengumpulan data yaitu wawancara, observasi dan dokumentasi. Penelitian ini menghasilkan tiga jenis data: kutiapan, uraian, dan kutipan dokumen menghasilkan dalam suatu produk: uraian naratif.

Menurut Moloeng (2008), triangulasi adalah teknik pemeriksaan keabsahan data yang memanfaatkan sesuatu yang lain. Di luar data untuk keperluan pengecekan atau sebagai pembanding terhadap data itu. Teknik triangulasi yang paling banyak digunakan ialah pemeriksaan melalui sumber lainnya. Denzin dalam Moloeng (2008) membedakan empat macam triangulasi sebagai teknik pemeriksaan yang memanfaatkan penggunaan sumber, metode, penyidik, dan teori. Triangulasi dilakukan melalui wawancara, observasi langsung dan observasi tidak langsung, observasi tidak langsung ini dimaksudkan dalam bentuk pengamatan atas beberapa kelakukan dan kejadian yang kemudian dari hasil pengamatan tersebut diambil benang merah yang menghubungkan di antara keduannya. Teknik pengumpulan data yang digunakan akan melengkapi dalam memperoleh data primer dan skunder. Observasi dan interview digunakan untuk menjaring data primer yang berkaitan, pengaruh prilaku komsumen terhadap permintaan minyak mandar, sementara studi dokumentasi digunakan untuk menjaring data skunder yang dapat diangkat dari berbagai dokumentasi tentang prilaku komsumen.Peneliti menggunakan teknik triangulasi sumber (data) dan triangulasi metode untuk menguji keabsahan data yang berhubungan dengan masalah penelitian yang diteliti oleh peneliti.

\section{Hasil Dan Pembahasan}

Hasil penelitian berupa kutipan wawancara menjelaskan jawaban informan mengenai faktor yang mempengaruhi permintan komsumen terhadap Produk 
minyak kelapa (minyak mandar) oleh responden. Adapun faktor yang mempengaruhi prilaku komsumen terhadap permintan minyak mandar yang terkandung dalam kutipan hasil wawancara tersebut didasarkan pada teori yang dikemukakan oleh Kotler (20012:162), yang menyatakan bahwa faktor yang mempengaruhi keputusan pembelian antara lain faktor Produk, harga, tempat, dan promosi - yang diperlukan perusahaan untuk menghasilkan respons yang diinginkannya dipasar sasaran. Selain itu ada 2 faktor yang di temukan peneliti yang sangat erat kaitannya terhadap perilaku komsumen yaitu faktor budaya dan ekonomi ( pendapatan rumah tangga) Faktor Harga.

Harga merupakan salah satu faktor penentu dalam pemilihan merek yang berkaitan dengan keputusan membeli konsumen (Kotler dan Keller, 2014). Ketika memilih diantara merek yang ada konsumen akan mengevaluasi harga secara tidak mutlak akan tetapi dengan membandingkan beberapa standar harga sebagai referensi untuk melakukan transaksi pembelian. Berdasarkan pernyataan tersebut dapat dikatakan bahwa harga memang mempengaruhi keputusan pembelian konsumen. Hasil wawancara dengan informan mengenai pengaruh harga terhadap keputusan pembelian dari 43 orang responde 36 orang dengan jumlah persentase sebesar $83,72 \%$ menjawab berpengaruh sedangkan yang menjawab tidak sebesar 7 orang dengan jumlah persentase sebesar $18,60 \%$ disajikan dalam bentuk kutipan berikut.

Berikut ini Jawaban responden dari berpengaru sampai tidak berpengaru setiap kategori jawaban di wakili 5 kutipan hasil wawancara diperoleh jawaban yaitu:

Kutipan jawaban dengan marawia (55) didapatkan jawaban yaitu:

"Tidak, karena walaupun harganya sekarang ini semakin mahal, namun masih tetap terjangkau oleh konsumen, meskipun uang kami tidak cukup membeli 1 botol kami bisa membeli $1 / 2$ atau $1 / 3$, jadi dari segi harga kami bisa ngengatasinyan dengan membeli sesuai dengan kemampuan kami”.

Kutipan jawabandengan sri wahyuni (23) diperoleh jawaban yaitu:

"ya berpengaruhi, di karenakan kulitas yang di tawarkan dan cara pengolahannya yang masih tradisional wajarlah harganya yang relatip mahal.

Kutipan jawaban dengan H.Arif ( 43) didapatkan jawaban yaitu:

"Ya berpengaruh, dikarenakan kalau urusan dalam pembelian disesuaikan dengan kondisi ekonomi,

Kutipan jawaban dari seluruh informan di atas memperlihatkan bahwa harga memang mempengaruhi keputusan pembelian seseorang. Pernyataan ini didukung oleh pendapat dari Kotler dan Keller, (2012:203) yang menyatakan bahwa harga merupakan salah satu faktor penentu dalam pemilihan merek yang berkaitan dengan keputusan membeli konsumen. Artinya semakin mahal harga minyak mandar, maka cenderung keputusan pembelian oleh konsumen semakin rendah, sebaliknya semakin murah atau terjangkau harga maka semakin besar keputusan pembeliannya terhadap minyak mandar. Faktor utama keputusan pembelian adalah faktor ekonomi komsumen, semakin tinggi status ekonomi seseorang maka samakin selefti dalam memenuhi kebutuhannya. Mereka tidak memikir harga tapi lebih cenderung dari maaf barang tersebut.

\section{Faktor Kualitas Produk}

Produk adalah segala sesuatu yang dapat ditawarkan ke pasar/pembeli untuk mendapatkan perhatian, dibeli, digunakan, atau dikonsumsi yang dapat memuaskan keinginan atau kebutuhan (Kotler dan Armstrong, 2012:197).Dalam kaitannya dengan keputusan membeli, faktor produk mempunyai peran yang sangat penting karena terkait dengan keuntungan dan nilai yang ditawarkan kepada konsumen. Jika keuntungan serta nilai yang didapat konsumen setelah mengkonsumsi produk sesuai atau bahkan lebih besar dari harapan mereka maka kemungkinan untuk membeli atau memakai produk tersebut kembali akan lebih besar dan sebaliknya.

Hal ini senada dengan pendapat dari Kotler dan Amstrong (20012, 178) bahwa semakin baik kualitas produk yang dihasilkan maka akan memberikan kesempatan kepada konsumen untuk melakukan keputusan pembelian. Dari 43 orang responde 35 orang dengan jumlah persentase sebesar $81,40 \%$ menjawab berpengaruh sedangkan yang menjawab tidak sebesar 8 orang dengan jumlah persentase sebesar 18,60\%. Jawaban komsumen tentang pengaruh kualitas produk terhadap keputusan pembelian disajikan dalam kutipan berikut.

Kutipan jawaban dari Rohani (31) sebagai berikut:

"Ya, menurut saya minyak goreng mandar lebih baik dari minyak goreng lain, karena pengolahannya yang masih tradiosonal dan tanpa bahan pengawet tidak dengan merek yang lain.

Kutipan jawaban dari Asmira (29) sebagai berikut

"Ya, sangat berpengaruh, karena kualitas bagus, di karenakan kita bisah melihat cara pengolahan terus tidak ada bahan yang lain yang di campurkan kedalam pembuatan minyak mandar.

Kutipan jawaban dari Ahma rahma (51) sebagai berikut"Tidak mempengaruhi , karena saya tau minyak goreng mandar lebih bagus dari segi warna,aroma dan rasa tetapi saya $\mathrm{t}$ membeli minyak goreng lain di karenakan disesuaka dengan ekonomi keluarga.

Kutipan jawaban dari Kamaria (50) sebagai berikut"Ya,berpengaruh, karena kualitas minyak goreng mandar lebih bagus, dari aroma masakan yang kita masak lebih wangi,

Kutipan jawaban dari Mastura (29) sebagai berikut"Ya, karena kualitas minyak goreng mandar lebih bagus,warna dari minyak goren mandar tidak cepat berubah saat di pake dalam mengoreng dan aroma ciri khas dari minyak mandar ada pada setiap gorengan beda dengan minyak goreng merek lain.

Berdasarkan pernyataan dari para responden di atas, maka dapat diketahui bahwa kualitas produk berpengaruh terhadap keputusan pembelian. Hal ini senada dengan pendapat dari Kotler dan Amstrong 
(2012: 178) bahwa semakin baik kualitas produk yang dihasilkan maka akan memberikan kesempatan kepada konsumen untuk melakukan keputusan pembelian. Dengan kata lain semkin baik minyak mandar, maka semakin besar pula keputusan pembelian seseorang terhadap minyak goreng mandar, begitu sebaliknya.

Faktor lokasi dan Ketersediaan

Lokasi adalah tempat dimana suatu usaha itu didirikan.Ketersediaan produk sangat terkait erat dengan distribusi produk, dimana produk yang dihasilkan atau ditawarkan oleh penjual disalurkan hingga sampai kepada konsumen akhir untuk memenuhi keinginan atau kebutuhannya. Beberapa saluran distribusi yang agar produk dapat sampai kepada konsumen akhir atau pembelian antara lain agen, toko-toko, serta pengecer. Adanya saluran distribusi tersebut memastikan bahwa ketersediaan produk selalu terpenuhi maka konsumen dapat dengan mudah memperolehnya, sehingga akhirnya mempengaruhi keputusan pembelian pada produk tersebut.Berdasarkan uraian ini, maka dapat diketahui bahwa semakin banyak saluran distribusi, maka semakin banyak pula ketersediaan produk, yang pada akhirnya berdampak pada semakin besar keputusan konsumen untuk membeli produk tersebut. Hasil wawancara dengan informan mengenai pengaruh ketersediaan produk terhadap keputusan pembelian Dari 43 orang responde 32 orang dengan jumlah persentase sebesar 74,42\% menjawab berpengaruh sedangkan yang menjawab tidak sebesar 11 orang dengan jumlah persentase sebesar 25,58\% diungkapkan dalam kutipan jawaban sebagai berikut.

Kutipan jawaban dari Putri Rahma sebagai berikut"ya berpengaruh, mudah di dapat, karena masyarakat desa petampanua masih banyak yang meproduksi minyak goreng mandar.

Kutipan jawaban dari Nurhayati (38) sebagai berikut"ya tidak berpengaru, banyaknya warung yang menjual minyak goreng dalam stok yang cukup, hampir setiap warung di desa Patampanua menjual minyak goreng mandar tetapi saya biasa membeli minyak goreng merek yang lain .

Kutipan jawaban dari Rukiah (45) sebagai berikut"ya berpengaruh, karena produk minyak goreng mandar sering atau bahkan gampang sekali dicari di warung-warung, ketika di warung stoknya habis saya akanmencarinya lansung ke pembuat minyak goreng mandar.

Kutipan jawaban dari Purnama (38) sebagai berikut"ya berpengaruh, karena minyak goreng mandar selalu ada di warung di lingkungan saya beda dengan minyak goreng lain kandang stoknya tidak ada.

Kutipan jawaban dari Bada sebagai berikut"ya berpengaruh,karena warung di samping rumah saya stoknya selalu ada berbeda dengan dengan merek lain, dari pada saya harus mencari lagi minyak goreng yang lebih murah itukan mengeluar kan biaya dan tenaga lagi.

Berdasarkan kutipan jawaban dari para komsumen minyak goreng mandar, maka dapat disimpulkan bahwa ketersediaan produk sangat mempengaruhi keputusan pembelian konsumen, dengan kata lain ketersediaan produk dipertimbangan oleh individu ketika melakukan pembelian.

\section{Faktor Promosi}

Promosi adalah fungsi pemasaran yang fokus untuk mengkomunikasikan program-program pemasaran secara persuasive pada target audience (pembeli) untuk mendorong terciptanya transaksi pertukaran antara perusahaan dan audience/pembeli (Hasan, 2008: 125). Promosi mempunyai peran yang penting dalam mempengaruhi proses keputusan membeli oleh konsumen karena dapat menjadi sarana untuk menumbuhkan pengertian antara pihak produsen dan konsumen (Kotlet, 2012). Semakin sering promosi dilakukan, maka cenderung semakin besar keputusan pembelian konsumen pada produk yang dipromosikan tersebut.Berdasarkan uraian tersebut, dapat diketahui bahwa kegiatan promosi memang ditujukan untuk mempengaruhi keputusan pembelian konsumen. Dari 43 orang responde 25 orang dengan jumlah persentase sebesar $58,14 \%$ menjawab berpengaruh sedangkan yang menjawab tidak sebesar 18 orang dengan jumlah persentase sebesar $41,86 \%$.

Jawaban dari informan tentang pengaruh promosi terhadap keputusan pembelian seperti yang diungkapkan oleh Kamasia (33) sebagai berikut"Ya berpengaruh, saya tertarik minyak goreng mandar di karenakan salah seorang tetangga datang dirumah membawa gorengan yang di goreng pake minyak goreng mandar dia menjalaskan tentang aromanya berasal dari minyak gorengnya.Mulai dari situ saya mulai memakai minyak goreng mandar.

Begitu pula jawaban yang dikemukakan oleh Pati (28) seperti dalam kalimat kutipan berikut ini“Kalau saya sih berpengaruh, saya tertarik ketika saya melihat proses pembuatan dan di jelaskan proses pembuatan oleh pemilik usaha"

Pendapat yang tidak jauh berbeda dikatakan pula oleh Asmira (29) seperti yang tercantum dalam kutipan berikut ini yaitu"Ya, saya tertarik membeli minyak goreng mandar karena promosi yang dilakukan oleh pihak penjual pengecernya dari aroma dan warna selain itu dia menjelaskan bahwa minyak ini bagus buat winyak urut dan minyak rambut buat anak."

Lain halnya dengan Murmia (37) dan Sri Wahyuni (23) yang berpendapat promosi tidak berpengaruh terhadap keputusan pembelian, seperti kutipan hasil wawancara sebagai berikut.

Kutipan jawaban Murmia (37)“Tidak, karena saya orangnya gampang penasaran terhadap suatu prodak pertama kali saya membeli minyak mandar karena rasa penasaran tidak ada yang memberitahu saya apa maaf dan kulitas dari minyak.

Kutipan jawaban Sri Wahyuni (23)“Tidak pengaruh, karena saya membeli melihat manfaaf dan kulitas bukan promosi”.

Berdasarkan beberapa pernyataan seperti yang terdapat dalam kutipan jawaban informan di atas, maka dapat disimpulkan bahwa promosi berpengaruh terhadap keputusan pembelian seseorang. Hal ini didukung oleh Pendapat dari Kotlet, (2012) promosi mempunyai peran 
yang penting dalam mempengaruhi proses keputusan membeli oleh konsumen karena dapat menjadi sarana untuk menumbuhkan pengertian antara pihak produsen dan konsumen. Semakin sering promosi dilakukan, maka semaking banyak yang tau manfaat dan kulitas otomatis makin banyak yang akan mengkomsumsi barang tersebut.Seiring berjalan penelitian ini peneliti menemukan faktor yang lain yang mempengaruhi prilaku komsumen seperti faktor budaya, dan ekonomi

Faktor Budaya

Kebudayaan berpindah dari setiap generasi manusia, setiap generasi selalu melanjutkan apa yang telah mereka pelajari dan apa yang mereka sendiri tambahkan dalam budaya tersebut. Kebudayaan juga sebagai jalan arah di dalam bertindak dan berpikir sesuai dengan pengalaman yang sudah dimilikinya.Kebudayaan merupakan penentu keinginan dan perilaku yang paling mendasar untuk mendapatkan nilai, persepsi, preferensi dan perilaku dari lembaga-lembaga penting lainnya.Dalam kaitannya dengan keputusan pembelian dapat diketahui bahwa budaya menjadi acuan seseorang untuk melakukan pembelian, sehingga budaya mempengaruhi dalam keputusan pembelian.Hal ini sesuai pernyataan Kotler bahwa faktor budaya mempengaruhi keputusan pembelian. Dari 43 orang responde 27 orang dengan jumlah persentase sebesar $62,79 \%$ menjawab berpengaruh sedangkan yang menjawab tidak sebesar 16 orang dengan jumlah persentase sebesar 37,21\%. Berikut adalah kutipan hasil wawancara mengenai pengaruh budaya dalam keputusan pembelian.

Pernyataan dari saudari Rahmiati(41) dipaparkan sebagai berikut."Ya, sangat berpengaruh karena lingkungan tempat tinggal saya banyak pembuat minyak goreng mandar, sehingga lama kelamaan membuat saya tertarik dan pada akhirnya saya membeli minyak goreng mandar".

Pendapat yang sama pula dikemukan oleh Rukiah (45) yang dinyatakan "Ya, kalau saya bilang budaya berpengaruh, misalnya saya tinggal di daerah sini yang banyak orang-orang yang suka dan memproduksi, maka dengan otomatis saya juga menyukai lalu dan membeli minyak goreng mandar yang sering di komsumsi masyarakat sekitar sini".

Begitu pula dengan pernyataan seorang penguna yang sekaligus produsen yang juga menjadi responden penelitan ini yaitu Habibah (50), dia mengatakan bahwa.Ya, sangat berpengaruh banget karena lingkungan tempat tinggal saya terdapat banyak produsen sehingga lama-lama membuat saya tertarik membuat dan mengkomsumsi dengan minyak mandar".

Icci (30) menyatakan pendapat yang sebaliknya bahwa budaya tidak berpengaruh dalam keputusan pembelian seperti pernyataannya berikut ini."Tidak berpengaru, karena orang lain di lingkungan tempat tinggal saya banyak produsen minyak mandar, saya membeli minyak goreng merek lain untuk memenuhi kebutahan kami.

Begitu pula dengan pernyataan Pati Japarang yang mendukung pendapat dari Bassing sebagai
berikut."Tidak berpengaruh, karena di lingkungan tempat tinggal saya, hanya saya sajalah suka membeli minyak goreng merek lain, karena tuntukan ekonomi keluarga.

Dari pernyataan hasil wawancara dari para responden tersebut dapat diketahui bahwa kebudayaan berpengaruh terhadap keputusan pembelian pendapat ini didukung oleh pernyataan dari Kotler bahwa faktor budaya mempengaruhi keputusan pembelian artinya.Artinya bahwa konsumen memutuskan untuk membeli salah satu alasannya adalah karena faktor budaya.

\section{Faktor Pendapatan}

Menurut Sukirno (2009), pendapatan rumah tangga adalah penghasilan dari seluruh anggota rumah tangga yang disumbangkan untuk memenuhi kebutuhan keluarga ataupun perorangan anggota rumah tangga. Pendapatan seseorang dapat berubah dari waktu ke waktu sesuai dengan kemampuan mereka. Berubahnya pendapatan seseorang akan berubah pula besarnya pengeluaran mereka untuk konsumsi suatu barang. Pendapatan merupakan faktor yang penting dalam mempengaruhi konsumsi seseorang atau masyarakat terhadap suatu barang.

Berikut adalah kutipan hasil wawancara mengenai pengaruh pendapatan rumah tangga dalam keputusan pembelian.Dari 43 orang responde semuanya mengatakan bahwa faktor pendapatan berpengaruh terhada permintaan minyak mandar di dukung oleh jawaban dari saudara yang bernama Kasamia (33) dipaparkan sebagai berikut."Ya, sangat berpengaruh karena bagimana kita mau beli barang yang harganya mahal ketika penghasilan kita cukup untuk barang yang murah.

Pendapat yang sama pula dikemukan oleh Marawa yang dinyatakan "Ya, kalau saya sanagat berpengaruh, ketika saya memiliki uang yang cukup maka saya akan membeli persedian minyak goreng untuk satu bulan maka sebalinya ketika uang saya cukup untuk persedian untuk beberapa hari saja.

Pendapat yang sama pula dikemukan oleh Kamasia yang dinyatakan Ya,sangat berpengaruh banget karena untuk memenuhi kebutuhan kita sehari-hari kita harus mengukur dari tingkat pendapan kita.

Pendapat yang sama pula dikemukan oleh Tabia (40) yang dinyatakan "Berpengaru, bagaimana kita mau membeli minyak mandar kita tau minyak mandar harganya dengan penghasilan yang pas-pasan mending kita beli minyak yang lebih murah untuk mencukupi kebutuhan yang lain. Begitu sebalik kita penghasilan kita lebih harga tidak jadi masalah di karenakan kita memikir maaf dan fungsi daribarang tersebut.

Begitu pula dengan pernyataan $\mathrm{H}$. Arif (42) sebagai berikut."sangat berpengaruh, karena tingkat pendapatan akan mempengaruhi pola komsumsi kita meningkat akan berbagai jenis barang. Cantoh ketika pendapatan saya masih pas-pasan maka saya membeli minyak goren murah sekarang berbeda karena penghasilan saya bertamba maka saya lebih seleptif memilih minyak goreng soal harga nomor 2 kualitas yang utama 
Dari pernyataan hasil wawancara dari para responden tersebut dapat diketahui bahwa pendapatan sangat berpengaruh terhadap keputusan pembelian pendapat ini didukung oleh pernyataan dari Kotler (2012) bahwa perubahan tingkat pendapatan akan mempengaruhi banyaknya barang yang akan dikonsumsi. Bahkan seringkali dijumpai dengan bertambahnya pendapatan, maka barang yang dikonsumsi bukan saja bertambah tetapi juga melihat kualitas barang tersebut.Besar kecilnya barang yang diminta atau dikonsumsi tergantung pada besar-kecilnya pendapatan.Pada tingkat pendapatan rumah tangga yang rendah, maka pengeluaran rumah tangganya lebih besar dari pendapatannya. Semakin tiggi tingkat pendapatannya maka konsumsi yang dilakukan rumah tangga akan semakin besar pula permintan akan barang untuk memenuhi kebutuhannya.

\section{Kesimpulan}

Berdasarkan hasil penelitian maka ditarik kesimpulan berdasarkan penjelasan dan permasalahan yang ada di rumusan masalah tentang faktor yang mempengaruhi permintaan konsumen terhadap minyak kelapa ( mandar Mandar) di Desa Patampanua Kecamatan Matakali, Kabupaten Polewali Mandar" 1.Dalam penelitian ini peneliti menemukah ada 6 faktor yang mempengaruhi komsumen terhadap permintaan minyak kepala (minyak mandar) faktor harga, Faktor kualitas produk, Faktor lokasi dan tersedian produk, Faktor Promosi, Faktor Budaya dan Faktor Pendapatan 2.Permintaan komsumen terhadap minyak kelapa (minyak Mandar) cenderung dipengaruhi oleh

1. Harga, semakin mahal harga minyak mandar, maka keputusan pembelian oleh konsumen semakin rendah, sebaliknya semakin murah atau terjangkau harga maka semakin besar keputusan pembeliannya terhadap minyak mandar.

2. Kulitas produk, semakin baik kualitas minyak mandar, maka semakin besar pula keputusan seseorang pembelian terhadap minyak goreng mandar, begitu sebaliknya.

3. Faktor lokasi dan ketersediaan Adanya saluran distribusi memastikan bahwa ketersediaan produk selalu terpenuhi maka konsumen dengan mudah memperolehnya, sehingga akhirnya mempengaruhi keputusan pembelian pada produk tersebut.

4. Promosi, semakin sering promosi dilakukan, maka semaking banyak yang tau manfaat dan kulitas minyak mandar.

5. Budaya menjadi faktor penentu yang paling mendasar dari segi keinginan dan perilaku seseorang menentukan pola komsumsi.

6. Tingkat pendapatan akan mempengaruhi banyaknya barang yang akan dikonsumsi dengan bertambahnya pendapatan, maka barang yang dikonsumsi bukan saja bertambah tetapi juga melihat kualitas.

\section{Daftar Pustaka}

Hasan, Umar. (2008). Riset Pemasaran Dan Perilaku Konsumen.Jakarta : PT. Gramedia Building

Kotler, Philip and Gary Armstrong. 2012. Prinsip-prinsip Pemasaran. Edisi. 12. Jilid 1. Jakarta: Erlangga

(Kotler dan Keller, 2014 Prinsip-prinsip Pemasaran. Edisi. 12. Jilid 2. Jakarta: Erlangga

Meleong, (2008), "Metode Penelitian Kualitatif" Bandung, Remaja Rosdakarya

Sugiyono, 2011, Metodelogi Penelitian Kuantitatif, Kualitatif Dan R\&D. (Bandung: ALFABETA)

Utami, E.R. 2012. Antibiotika, Resistensi, dan Rasionalitas Terapi. Sainstis.Vol. 1.No. 1 AprilSeptember. 